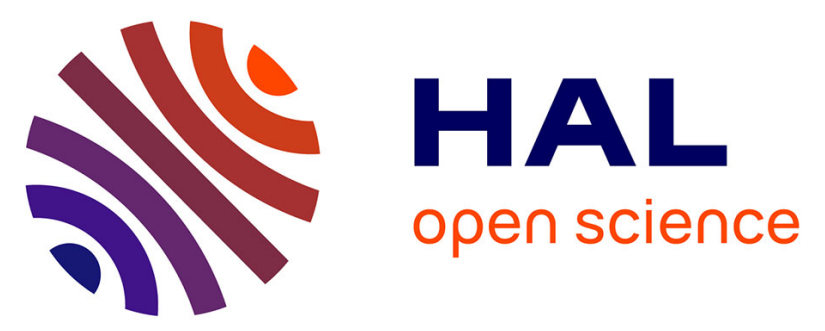

\title{
Low temperature dry reforming of methane on rhodium and cobalt based catalysts: active phase stabilization by confinement in the mesoporous SBA-15
}

\author{
N. El Hassan, M.N. Kaydouh, H. Geagea, H. Elein, Karam Jabbour, S. \\ Casale, H El Zakhem, Pascale Massiani
}

\section{To cite this version:}

N. El Hassan, M.N. Kaydouh, H. Geagea, H. Elein, Karam Jabbour, et al.. Low temperature dry reforming of methane on rhodium and cobalt based catalysts: active phase stabilization by confinement in the mesoporous SBA-15. Applied Catalysis A: General, 2016, 520, pp.114-121. 10.1016/j.apcata.2016.04.014 . hal-01305526

\section{HAL Id: hal-01305526 \\ https://hal.sorbonne-universite.fr/hal-01305526}

Submitted on 21 Apr 2016

HAL is a multi-disciplinary open access archive for the deposit and dissemination of scientific research documents, whether they are published or not. The documents may come from teaching and research institutions in France or abroad, or from public or private research centers.
L'archive ouverte pluridisciplinaire HAL, est destinée au dépôt et à la diffusion de documents scientifiques de niveau recherche, publiés ou non, émanant des établissements d'enseignement et de recherche français ou étrangers, des laboratoires publics ou privés. 
Low temperature dry reforming of methane on rhodium and cobalt based catalysts: active phase stabilization by confinement in the mesoporous SBA-15

$\underline{\text { N. El Hassan }}^{1 *}$, M.N. Kaydouh ${ }^{1,2}$, H. Geagea ${ }^{1}$, H. El Zein ${ }^{1}$, K. Jabbour ${ }^{1,2}$, S. Casale ${ }^{2,3}$, H. El

Zakhem $^{1}$, P. Massiani* ${ }^{2,3}$

${ }^{1}$ University of Balamand, Department of Chemical Engineering, P.O. Box 33 Amioun, El Koura, Lebanon

${ }^{2}$ Sorbonne Université, UPMC University Paris 06, Laboratoire de Réactivité de Surface, 4 place jussieu, 75005 Paris, France

${ }^{3}$ CNRS UMR 7197, UPMC, 4 place jussieu, case 178, 75005 Paris cedex, France

(*) corresponding authors: nissrine.hassan@balamand.edu.lb (N. El Hassan), pascale.massiani@upmc.fr (P. Massiani) 


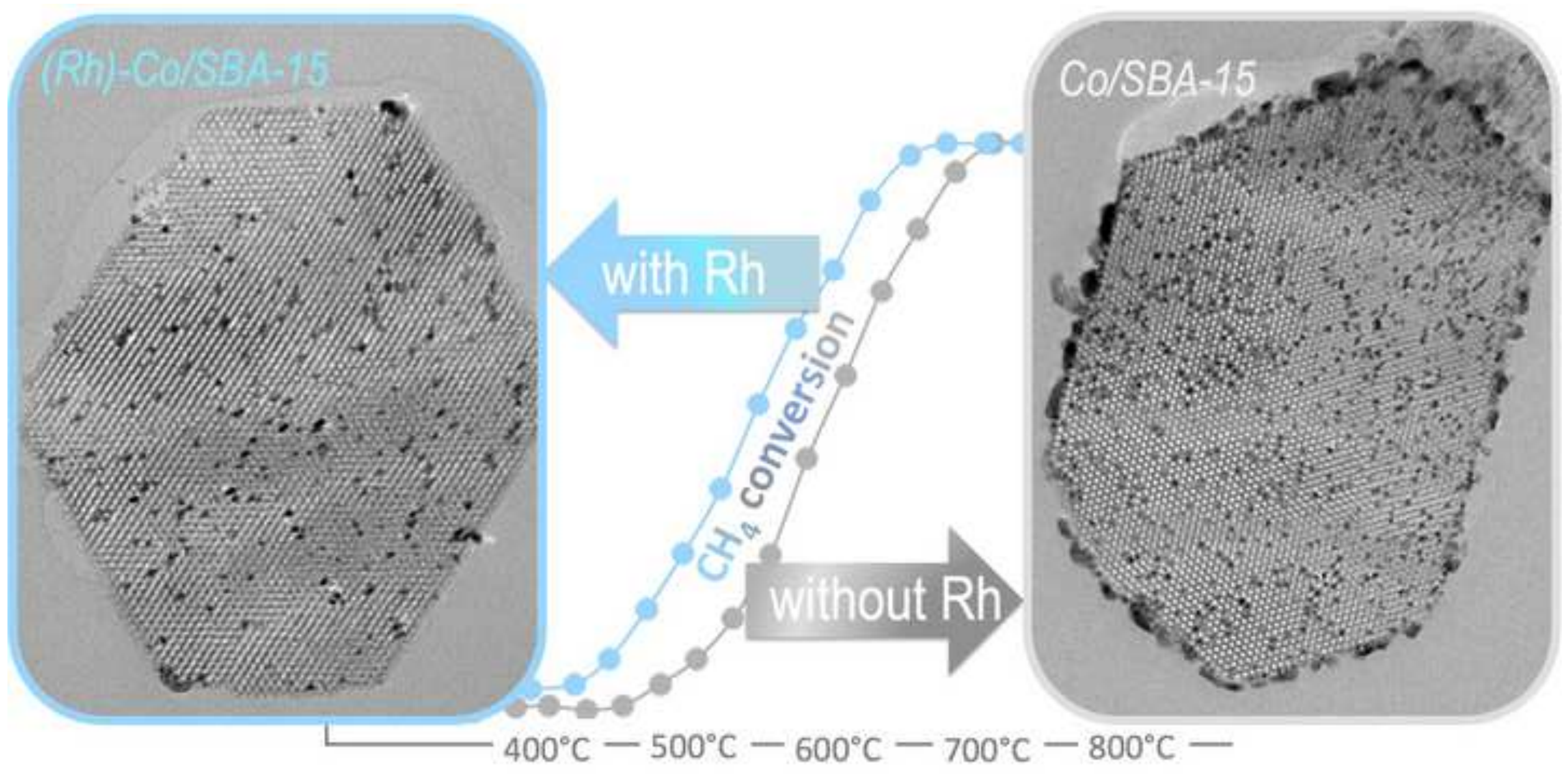


Highlights:

- Co nanoparticles are stabilized against sintering in the mesopores of SBA-15 during dry methane reforming.

- The decrease of reduction temperature in presence of Rh leads to more numerous Co species confined in the pores.

- Deactivating carbons are formed in lower amount in presence of both rhodium and cobalt. 


\begin{abstract}
Two silica supports either non porous $\left(\mathrm{SiO}_{2}\right)$ or mesoporous (SBA-15) were impregnated with cobalt $(12 \mathrm{wt} \%)$ in order to study the confinement effect on catalytic performances in dry reforming of methane. Further increase of activity was obtained by adding small amounts of rhodium (0.2 and $0.5 \mathrm{wt} \%)$ to the Co/SBA-15 catalyst. The structural and morphological properties of the calcined samples were characterized by $\mathrm{N}_{2}$ sorption, X-ray diffraction and highresolution transmission electron microscopy (ultra-thin sections). Their reducibility was studied by temperature-programmed reduction. After in situ reduction of the materials, their catalytic activity was tested in dry reforming of methane up to $800^{\circ} \mathrm{C}$ followed by stability testing at $550^{\circ} \mathrm{C}$ for 550 minutes. Cobalt confinement in the mesopores of SBA-15 is shown to be highly beneficial towards not only activity but also stability, the reduced nanoparticles being then more resistant against sintering under stream. Rh plays a role as an additional active phase. It also strongly favors cobalt stabilization in the mesopores by permitting its reduction at a much lower temperature, which allows avoiding metal migration to the surface of the silica grains. The nature of coke is also shown to depend on rhodium addition, with less amount of carbon gamma (graphitic and destructive form) formed on the Rh-containing sample compared to the $\mathrm{Rh}$-free Co/SBA-15 catalyst.
\end{abstract}

Keywords: Rhodium, cobalt, SBA-15, methane dry reforming, confinement effect 


\section{Introduction}

Nowadays, one of the major problems faced by industrial societies is global warming. Two of the most abundant greenhouse gases are carbon dioxide $\left(\mathrm{CO}_{2}\right)$, largely produced by human activities, and methane $\left(\mathrm{CH}_{4}\right)$, which is the major component of natural gas and has a global warming potential 25 times higher than that of $\mathrm{CO}_{2}$. Methane can be used to produce energy by combustion in air but one drawback of this energy resource lies in the large amounts of natural gas located in remote areas, so their transportation is very expensive. Therefore, the conversion of methane into heavier - more easily transportable - compounds such as liquid fuels (substitute of petroleum feedstock) represents an attractive and challenging target, offering environmental as well as economical and energetic benefits [1].

The available processes for the conversion of methane into liquid fuels currently consist in two main steps: methane is converted by reforming reaction to a gaseous mixture consisting of mainly hydrogen and carbon monoxide, called synthesis gas (or syngas), then the syngas is transformed to hydrocarbons by appropriate routes [2]. At present, the first step of methane reforming is commonly carried out in industry by steam reforming in the presence of water $\left(\mathrm{CH}_{4}\right.$ $+\mathrm{H}_{2} \mathrm{O} \rightarrow 3 \mathrm{H}_{2}+\mathrm{CO}$ ). However, dry reforming of methane (DRM) in which carbon dioxide is used as co-reactant $\left(\mathrm{CH}_{4}+\mathrm{CO}_{2} \rightarrow 2 \mathrm{H}_{2}+2 \mathrm{CO}\right)$ could bring two important advantages [3]. Firstly, the consumption of $\mathrm{CO}_{2}$ together with $\mathrm{CH}_{4}$ in DRM allows the simultaneous valorization of these two greenhouse gases into molecules with higher added value. Secondly, the syngas obtained from DRM has an equimolar composition $\left(\mathrm{H}_{2}: \mathrm{CO}\right.$ ratio of 1$)$ that is the best suited for direct use in Fischer-Tropsch (FT) synthesis to produce hydrocarbons with high yield [2]. By comparison, the $\mathrm{H}_{2}: \mathrm{CO}$ ratio is much higher (in the order of 3) in the case of methane steam 
reforming and adjustments, such as the addition of a membrane separation unit to the process, are then required before FT synthesis can be performed.

In spite of the above mentioned benefits, dry reforming of methane still faces several difficulties that need to be overcome before any application of the process at an industrial scale can be foreseen. Compared to steam reforming, this reaction is thermodynamically favored at higher temperatures and it is therefore carried out under conditions (usually above $650^{\circ} \mathrm{C}$ ) in which the catalysts can suffer fast deactivation by sintering of the active phase and by coke deposition, the latter also possibly leading to reactor blockage. Amongst the metals $(\mathrm{Pt}, \mathrm{Pd}, \mathrm{Rh}$, Ir, $\mathrm{Ru}, \mathrm{Ni}, \mathrm{Co}$ ) already tested in DRM [4,5], noble metals are recognized as the most stable ones. Nevertheless, their limited availability and high cost represent a major drawback for industrial use. Alternatively, nickel-based catalysts have been extensively studied in the last decade due to their high activity in DRM, however improvement of their stability is still needed and this represents an active field of research, as recently reviewed [6]. By comparison to $\mathrm{Ni}$, fewer attention has been devoted to Co, less performing in DRM but having however the advantage of less coke deposition [7-17]. From this point of view, studies dedicated to the increase of the activity of Co-based catalysts in DRM while keeping their good stability appear highly relevant. Interestingly, bi-metallic Ni-Co catalysts were recently investigated in dry reforming of methane and they were found more stable than Ni-based ones [17-21]. Furthermore, we showed in a recent paper that cobalt activity in DRM could be enhanced by dispersion of the metal nanoparticles in a SBA-15 silica support [15]. Such type of mesoporous support was already found to favor high cobalt oxide dispersion [22-24]. Furthermore, for Ni-based systems, it was shown to provide a very efficient way to increase catalysts stability in DRM by protecting the 
metal nanoparticles against sintering and coke deposition through their stabilization inside the SBA mesopores [25-31].

Another way to increase the performances of transition metal catalysts in DRM is the addition of dopants, often a noble metal in low amounts. This has been already well demonstrated for Ni-based catalysts [32-36] but more rarely studied in the case of Co-based ones. Nevertheless, we observed in a recent paper that doping Co/SBA-15 catalysts by small amounts of ruthenium can lead to increased performances in DRM, even if the catalysts still suffered from some lack of stability due to formation of carbon derivatives [15]. In this respect, rhodium could be a more appropriate doping agent since it was identified as an efficient promoter of nickel over different oxide supports such as boron nitride [37], alumina [38], silica [39] or MCM-41 [40]. A similar effect was also very recently reported on Co/alumina [12]. Even though a promotional effect of rhodium on cobalt was claimed in these previous studies, there is no evidence of a real synergetic effect, rhodium being possibly simply involved as additional active phase for the dry reforming reaction. To clarify this point, it is of interest to compare the activity of bimetallic catalysts containing both cobalt and rhodium phases to those loaded with only either rhodium or cobalt.

Based on these considerations, the aim of this study was to enhance the activity of Co-based catalysts in DRM, as well as their resistance against active phase sintering and coke deposition, by combining two effects: (i) the addition of low amounts of rhodium that could play the role of either a promoter or of a complementary active phase and (ii) the stabilization of the cobalt species by confining them in the channels of mesoporous SBA-15 silica. To this end, Rh/SBA-15 (reference), $\mathrm{Co} / \mathrm{SBA}-15$ and $\mathrm{Rh}-\mathrm{Co} / \mathrm{SBA}-15$ catalysts were prepared, their structural and morphological properties were identified and their performances in dry reforming of methane 
were compared up to $800^{\circ} \mathrm{C}$. A non-porous Rh-free Co-containing sample with commercial silica as support was also prepared for comparison. For stability measurements, we chose to carry out the reaction at $550^{\circ} \mathrm{C}$ because working at such medium temperature would allow using such systems in membrane reactors without losing the permeation of the membrane $[41,42]$. It is worth noting that in spite of such potentiality, only few studies describe the performances of methane dry reforming catalysts at such medium temperatures [13,15,43-46].

\section{Experimental}

\section{$\underline{\text { 2.1 Catalysts Preparation }}$}

The mesoporous SBA-15 support was prepared according to a well-known method [47]. After drying, the powder was calcined in a muffle furnace (Nabertherm) at $500^{\circ} \mathrm{C}$ for 9 hours (heating rate $\left.2^{0} \mathrm{C} \cdot \mathrm{min}^{-1}\right)$. The cobalt active phase $(12 \mathrm{wt} \%)$ was deposited by a two solvents method [48,49] using cobalt (II) nitrate hexahydrate (Sigma Aldrich, 239267) as cobalt precursor: briefly, $1 \mathrm{~g}$ of support was suspended in $20 \mathrm{~mL}$ of $\mathrm{n}$-hexane for few minutes, then an appropriate amount of solution containing the metal salt precursor was added drop by drop with manual stirring. After drying at room temperature for 24 hours, the sample was calcined in a muffle furnace at $450^{\circ} \mathrm{C}$ for 5 hours (heating rate $0.5^{\circ} \mathrm{C} \cdot \mathrm{min}^{-1}$ ) to give sample $\mathrm{Co}_{12} / \mathrm{SBA}-15$. Two different rhodium loadings $(0.2$ and $0.5 \mathrm{wt} \%)$ were then added to this material by the two solvents method, using rhodium (III) nitrate hydrate (Sigma Aldrich, 83750) as Rh precursor salt. The samples obtained after calcination (same conditions as for $\mathrm{Co}_{12} / \mathrm{SBA}-15$ ) are labeled $\mathrm{Rh}_{\mathrm{x}} \mathrm{Co}_{12} / \mathrm{SBA}-15$ where $\mathrm{x}$ is the $\mathrm{Rh}$ content (in wt $\%$ ). A Co-free reference sample with $0.5 \mathrm{wt} \%$ Rh (labeled $\mathrm{Rh}_{0.5} / \mathrm{SBA}-15$ ) was similarly prepared from the parent SBA-15 support. Moreover, a 
non-porous silica based sample (denoted $\mathrm{Co}_{12} / \mathrm{SiO}_{2}$ ) was prepared using fumed silica (Sigma Aldrich 381276), following the same procedure as for the $\mathrm{Co}_{12} / \mathrm{SBA}-15$ sample.

\subsection{Characterization techniques}

$\mathrm{N}_{2}$ sorption experiments were performed on an ASAP 2020 Micrometrics. Prior to analysis, each sample was outgassed under vacuum $\left(10^{-5}\right.$ bar $)$ for 2 hours at $250^{\circ} \mathrm{C}$. The external surface areas were calculated from the BET equation applied at relative pressures between 0.05 and 0.25 . The microporous volumes were estimated using the t-plot method; the obtained values were subtracted from the total porous volumes measured at $\mathrm{P} / \mathrm{P}_{0}=0.998$ to evaluate the mesoporous volumes. The average pore size diameters were estimated by the $\mathrm{BJH}$ methodology applied to the desorption branch of the isotherms.

X-Ray Diffraction (XRD) experiments were performed on a Panalytical XPert ${ }^{3}$ diffractometer using $\mathrm{CuK} \alpha$ radiation $(\lambda=1.54 \mathrm{~nm})$ and operating at $30 \mathrm{kV}$ and $10 \mathrm{~mA}$. All diffractograms were registered in the angular range $5^{\circ}<2 \Theta<90^{\circ}$. The crystallite sizes were calculated from the full width at half maximum (FWHM) of the peak at $65^{\circ}$ (440 reticular plan), using the Scherrer's equation and assuming spherical morphologies.

High Resolution Transmission Electron Microscopy (HRTEM) experiments were conducted on a JEOL JEM-200 electron microscope operated at $200 \mathrm{keV}\left(\mathrm{LaB}_{6}\right.$ gun) and equipped with an energy dispersive X-ray spectroscopy (EDXS). The preparation method of the ultra-thin sections was done as described in a previous work [22]. In order to determine the average particle size of cobalt oxides (on fresh calcined catalysts) or metallic cobalt nanoparticles (on spent catalysts), the software "Comptage des Particules" was used. 
Temperature Programmed Reduction (TPR) experiments were conducted on the fresh catalysts using an Autochem 2920 Micrometrics. During these experiments, the use of a cooling bath (ice and $\mathrm{NaCl}$ salt at $-10{ }^{\circ} \mathrm{C}$ ) allowed to trap all the water (desorbed or produced during reduction) and thus ensure that all TCD signal is related to $\mathrm{H}_{2}$ consumption. The flow rate of the $5 \mathrm{vol} \% \mathrm{H}_{2} / \mathrm{Ar}$ mixture was $20 \mathrm{~mL} \cdot \mathrm{min}^{-1}$ and the temperature was increased from room temperature to $900^{\circ} \mathrm{C}$ at $10^{\circ} \mathrm{C} \cdot \mathrm{min}^{-1}$.

Combined Temperature Programmed Hydrogenation and Mass Spectrometry (TPH-MS) studies were carried out on spent catalysts up to a maximum temperature of $900^{\circ} \mathrm{C}$ (heating rate of $10^{\circ} \mathrm{C} \cdot \mathrm{min}^{-1}, 5 \mathrm{vol} \% \mathrm{H}_{2} / \mathrm{Ar}$ flow of $\left.30 \mathrm{ml} \cdot \mathrm{min}^{-1}\right)$. The same apparatus and same cooling trap as for TPR was used and the exit gas lines were connected to an online quadrupole mass spectrometer (MKS, Cirrus 2) for exhaust gas analysis. The deposited carbon was classified according to its temperature of gasification: $\mathrm{C} \alpha$ up to $350^{\circ} \mathrm{C}, \mathrm{C} \beta$ between 350 and $500^{\circ} \mathrm{C}$ and $\mathrm{C} \gamma$ above $500^{\circ} \mathrm{C}$ [31]. The origins of these distinct carbon deposits (as reported in the literature) will be detailed in section 3.4.

\section{$\underline{2.3 \text { Catalytic tests }}$}

Prior to reaction, the calcined sample $(80 \mathrm{mg})$ was placed in the reactor and a pretreatment under 5 vol\% $\mathrm{H}_{2} / \mathrm{Ar}$ flowing at $20 \mathrm{~mL} \cdot \mathrm{min}^{-1}$ was performed. The temperature was increased from room temperature up to $650^{\circ} \mathrm{C}$ (heating rate $10^{\circ} \mathrm{C} \cdot \mathrm{min}^{-1}$ ) and kept at $650{ }^{\circ} \mathrm{C}$ for two hours. Then the temperature was decreased to $200^{\circ} \mathrm{C}$ before an equimolar mixture of $\mathrm{CH}_{4}$ and $\mathrm{CO}_{2}$ diluted in argon was introduced into the reactor. The temperature was next increased up to $800^{\circ} \mathrm{C}$ (heating rate $\left.5^{\circ} \mathrm{C} \cdot \mathrm{min}^{-1}\right)$ under a total GHSV of $67 \mathrm{~L} \cdot \mathrm{g}^{-1} \cdot \mathrm{h}^{-1}$. The composition of the effluent feed $\left(\mathrm{CH}_{4}\right.$ and $\mathrm{CO}_{2}$ as reactants and $\mathrm{CO}$ and $\mathrm{H}_{2}$ as main products) was measured using a Inficon Micro-GC 
equipped with two columns (Molecular Sieve and Plot-U) and a TCD detector. An ice-salt trap was also used at the exit of the reactor to trap any water that can be formed during the reaction. Finally, the reactor was cooled down to $550^{\circ} \mathrm{C}$ in order to run the stability test for 550 minutes. The reactants conversions were calculated as follows: $\mathrm{CH}_{4}$ conversion $=\left(\mathrm{CH}_{4 \text { in }}-\mathrm{CH}_{4 \text { out }}\right) / \mathrm{CH}_{4 \text { in }}$ and $\mathrm{CO}_{2}$ conversion $=\left(\mathrm{CO}_{2 \text { in }}-\mathrm{CO}_{2 \text { out }}\right) / \mathrm{CO}_{2 \text { in }}$. Note that these values take into account all consumed reactants (no longer present in the flow at the exit of the reactor), which includes not only those converted by main DRM reaction but also those involved in side reactions (particularly $\mathrm{C}$ deposits and reverse water gas shift).

\section{Results and discussion}

\section{$\underline{3.1 \text { Textural and structural properties }}$}

For the SBA-15 based samples, the $\mathrm{N}_{2}$ sorption isotherms are of type IV (Fig. 1), typical of mesoporous SBA-15 silica materials. This indicates that the hexagonal pore system of the parent SBA-15 support was systematically preserved after impregnation(s) and calcination(s) treatments, confirming the good stability of the synthesized support, already highlighted in previous papers $[14,22,23]$. Both microporous and mesoporous volumes decreased after cobalt addition, and the effect was accentuated after rhodium addition (Table 1 and Fig. 1). Such decrease is attributable to partial filling of the pores by metal species and/or to some collapse of the silica walls during successive impregnation and calcination treatments. Similarly, amongst metal loaded SBA-15 samples, the total surface area is the highest for $\mathrm{Rh}_{0.5} / \mathrm{SBA}-15$ (low metal loading, one impregnation step), it is intermediate for $\mathrm{Co}_{12} / \mathrm{SBA}-15$ (high metal loading, one impregnation step) and it is the lowest for $\mathrm{Rh}_{0.5} \mathrm{Co}_{12} / \mathrm{SBA}-15$ (high metal loading, two impregnation steps). Note also, the significant decrease of the micropores volume in all samples, 
showing their sensitivity to shrinking during impregnation treatments in solution then calcination. This, however, did not modify the average pore diameter that remains comparable in all materials, between 3.6 and $3.8 \mathrm{~nm}$ (Table 1). As expected, the surface area of the $\mathrm{Co}_{12} / \mathrm{SiO}_{2}$ was the lowest $\left(171 \mathrm{~m}^{2} \cdot \mathrm{g}^{-1}\right)$.

\section{Figure 1 and Table 1}

Figure 2 shows XRD patterns of calcined samples at wide angles $\left(2 \theta\right.$ range $\left.15-85^{\circ}\right)$. The wide peak at around $23^{\circ}$ is due to diffusion effects by the amorphous silica. All thinner peaks between $30^{\circ}$ and $70^{\circ}$ (identified by $*$ ) are typical of cobalt oxide $\mathrm{Co}_{3} \mathrm{O}_{4}$ with a face-centered cubic lattice

and a unit cell parameter of $8.084 \AA$ (JCPDS 43-1003). After Rh enrichment, no additional peaks were detected, as currently observed for low (and well dispersed) metal contents. Rhodium was nevertheless detected on the Co-free sample (tiny peak at around $44^{\circ}$ - identified by a circle on the figure - characteristic of rhodium oxide, JCPDS 75-3848). For the Co-containing SBA-15 samples, the comparable intensities and widths of the XRD peaks reveal that the mean size of the $\mathrm{Co}_{3} \mathrm{O}_{4}$ nanoparticles is close in all samples, with however a slight decrease when rhodium is present: this size is thus around $8.6 \mathrm{~nm}$ in $\mathrm{Co}_{12} / \mathrm{SBA}-15$ and $7.1 \mathrm{~nm}$ on both $\mathrm{Rh}_{0.2} \mathrm{Co}_{12} / \mathrm{SBA}-15$ and $\mathrm{Rh}_{0.5} \mathrm{Co}_{12} / \mathrm{SBA}-15$ (Table 1). The size value is much higher in $\mathrm{Co}_{12} / \mathrm{SiO}_{2}$, close to $16 \mathrm{~nm}$, in agreement with the non-porous character of the support.

\section{Figure 2}

The cobalt dispersion in the calcined samples and the location of the nanoparticles on the support were also analyzed by transmission electron microscopy. The observations were carried out on ultra-thin sections (microtomic slices) in order to facilitate the identification of the internal porosity and thus avoid any ambiguity between internal and external locations, as can 
occur on SBA-15 grains due to their thickness. Figure 3 shows typical micrographs obtained for $\mathrm{Rh}$-free $\mathrm{Co}_{12} / \mathrm{SBA}-15$ (images a to $\mathrm{c}$ ) and for $\mathrm{Rh}$ containing $\mathrm{Rh}_{\mathrm{x}} \mathrm{Co}_{12} / \mathrm{SBA}-15$ materials (images $\mathrm{a}^{\prime}$ to $\left.\mathrm{c}^{\prime}\right)$. On these images, the mesoporous SBA-15 support appears in grey while the metal nanoparticles appear darker due to their higher electronic density. When the silica grain is parallel to the electronic beam, one can easily observe the channels arrangement (Fig. 3a,a'); the other orientation (grain perpendicular to the electronic beam) permits the observation of the very regular hexagonal pore apertures (Fig. 3b,b'), especially at high magnification (Fig. 3c,c').

\section{Figure 3}

In both orientations, partial filling of the pores by occluded cobalt oxide nanoparticles is clearly seen. The nanoparticles are in majority located inside the pores, with however a significant fraction outside in the case of $\mathrm{Rh}$-free $\mathrm{Co}_{12} / \mathrm{SBA}-15$, appearing as big particles located at the silica surface (Fig. 3a-c). Such external particles, particularly well visible on highresolution images of grains orientated perpendicular to the beam (Fig. 3c), are on the contrary absent - or at least much less numerous - when $\mathrm{Rh}$ is present, in addition to Co, in the sample (Fig. 3a'-c'). Statistical particle diameter counting was done for all samples, on images taken perpendicular to the channels, by considering at least 500 nanoparticles inserted in the pores (see typical image, Fig. 4a), which led to rather narrow size distributions in all samples. The average size of about $8.1 \mathrm{~nm}$ thus found for $\mathrm{Co}_{12} / \mathrm{SBA}-15$ is slightly smaller than the size estimated from XRD (Table 1), in line with the presence in this sample of bigger external particles that are not considered in the TEM evaluation. On the contrary, both HRTEM and XRD size estimations are quite consistent for both $\mathrm{Rh}_{0.2} \mathrm{Co}_{12} / \mathrm{SBA}-15$ and $\mathrm{Rh}_{0.5} \mathrm{Co}_{12} / \mathrm{SBA}-15$ (Table 1), confirming that cobalt in these Rh-enriched samples is predominantly located inside the SBA-15 mesopores. It can be also noted that the average size values thus estimated are higher (around 7-8 $\AA$ ) than the 
pore diameters evaluated above (below $4 \AA$ ). This can be explained in part by the presence of external nanoparticles on the surface of the silica grains and by the aggregated ones appearing in the form of elongated chains on the HRTEM images recorded in parallel direction (Fig. 4b,c). Moreover, it can be recalled that such occurrence of confined nanoparticles slightly bigger than the average pore diameter is often observed in the case of zeolites, suggesting that some local framework destruction takes place during nanoparticle growth, leading to a small increase of the channel diameter around the particle. In fact, careful observation of the HRTEM micrographs in Figures $3 \mathrm{c}$ and $\mathrm{c}^{\prime}$ confirms the bigger diameter of the occluded nanoparticles compared to the channels. On the images of the calcined $\mathrm{Rh}$-richest $\mathrm{Rh}_{0.5} \mathrm{Co}_{12} / \mathrm{SBA}-15$ sample, individual rhodium-based nanoparticles smaller than $1 \mathrm{~nm}$ can be also detected inside the pores (chemical nature confirmed by EDS), appearing as very small black spots well distributed on the silica supports (see arrows in Fig. 4d), independent of the elongated cobalt oxide aggregates. Interestingly, these nanoparticles are distinct from Co ones, suggesting that $\mathrm{Rh}$ and Co active sites do not form common bimetallic phases and should therefore behave as individual active phases during the catalytic act.

\section{$\underline{3.2 \text { Reducibility of the supported rhodium and cobalt oxide species }}$}

The TPR profiles obtained upon reduction of the calcined samples are compared in Figure 5. The non-porous $\mathrm{Co}_{12} / \mathrm{SiO}_{2}$ catalyst contains a majority of cobalt oxide reducible below $450^{\circ} \mathrm{C}$. Mesoporous $\mathrm{Co}_{12} / \mathrm{SBA}-15$ shows a peak centered at $350^{\circ} \mathrm{C}$ and a weaker one around $400^{\circ} \mathrm{C}$, both attributable to the reduction of $\mathrm{Co}_{3} \mathrm{O}_{4}$ particles but a broad intense signal above $600^{\circ} \mathrm{C}$ is also present, indicating reduction of cobalt species in stronger interaction with the support [50,51]. This difference between the two Rh-free samples shows that the interaction between cobalt oxides nanoparticles and their silica support depends on the textural and surface properties of the 
latter, SBA-15 favoring stronger interaction compared to non-porous fumed silica. After rhodium addition, the shape of the reduction profile drastically changed, due to hydrogen activation by the noble metal (and therefore easier reduction of all species, including cobalt). The overlapped peaks with maxima at around $110^{\circ} \mathrm{C}$ and $190^{\circ} \mathrm{C}$ are typical of the reduction of rhodium oxide $\mathrm{Rh}_{2} \mathrm{O}_{3}$ [52] and isolated $\mathrm{RhO}_{\mathrm{x}}$ [53], respectively. The broader overlapped peaks between 200 and $440^{\circ} \mathrm{C}$ correspond to the reduction of cobalt oxide species, which occurs at lower temperature than on $\mathrm{Co}_{12} / \mathrm{SBA}-15$ due to the above mentioned hydrogen activation and hydrogen spillover process in presence of rhodium $[15,53]$ and also possibly to some Rh-Co interaction. On these samples, full reduction is achieved at $650^{\circ} \mathrm{C}$ (temperature of in situ reduction before catalytic tests). The total hydrogen consumptions reported in table 1 for all the samples remain within the limits of the expected values, revealing the good accessibility of hydrogen to the active sites. Finally, cobalt free $\mathrm{Rh}_{0.5} / \mathrm{SBA}-15$ shows a single peak around $100^{\circ} \mathrm{C}$, a temperature that fits well with $\mathrm{Rh}_{2} \mathrm{O}_{3}$ reduction [52].

\section{Figure 5}

\subsection{Activity and stability in DRM}

After reduction under $5 \mathrm{vol} \% \mathrm{H}_{2} / \mathrm{Ar}$ at $650^{\circ} \mathrm{C}$ for $2 \mathrm{~h}$, the performances of the catalysts in dry reforming of methane were evaluated. For both Rh-free $\mathrm{Co}_{12} / \mathrm{SBA}-15$ and $\mathrm{Co}_{12} / \mathrm{SiO}_{2}$ catalysts, conversions of both $\mathrm{CH}_{4}$ (Fig. 6A) and $\mathrm{CO}_{2}$ (Fig. 6B) start to be detected around $500^{\circ} \mathrm{C}$. The process is facilitated in presence of $\mathrm{Rh}$, since such conversions start to be already observed about $100^{\circ} \mathrm{C}$ below, including in the absence of cobalt, which means that rhodium sites are more active at lower temperature than cobalt ones. At this low temperature, Co free $\mathrm{Rh}_{0.5} / \mathrm{SBA}-15$ is as active as $\mathrm{Rh}_{0.5} \mathrm{Co}_{12} / \mathrm{SBA}-15$, showing that rhodium is the only active phase participating to the reaction 
in these conditions, in spite of its low content compared to Co. Nevertheless, the situation is no longer the same when the temperature increases above $500^{\circ} \mathrm{C}$, since cobalt sites becomes also active. A significant amelioration of activity is then seen when combining Co and $\mathrm{Rh}$ in a same catalyst and, for the metal-richest $\mathrm{Rh}_{0.5} \mathrm{Co}_{12} / \mathrm{SBA}-15$ catalyst, the conversions are close to the maximum thermodynamic limit values allowed for the applied test conditions [25]. On this catalyst, full conversion of methane is reached below $650^{\circ} \mathrm{C}$ while the highest $\mathrm{CO}_{2}$ conversion is

attained at around $700^{\circ} \mathrm{C}$. This temperature is lower than that previously observed for Ni/SBA15 catalysts studied in comparable conditions on which reactant conversions were below $90 \%$ at $650^{\circ} \mathrm{C}$ [25]. This attests of the very good performances of the Co and Rh enriched SBA-15 materials, in which both metals participate to the reaction, most probably in a separate way, in view of both TEM and catalytic data.

\section{Figure 6}

From stability experiments (Fig. 7) carried out at $550^{\circ} \mathrm{C}$, it can be seen that all catalysts are fully stable under stream for $500 \mathrm{~min}$. This figure highlights again the limited conversion level obtained at this temperature with cobalt alone $\left(\mathrm{Co}_{12} / \mathrm{SBA}-15\right.$ and $\mathrm{Co}_{12} / \mathrm{SiO}_{2}$ catalysts $)$, much below than with $\mathrm{Rh}_{0.5} / \mathrm{SBA}-15$ in spite of the lower metal content (and therefore smaller number of active sites) in the latter. The good performances of $\mathrm{Rh}_{0.5} \mathrm{Co}_{12} / \mathrm{SBA}-15$ compared to $\mathrm{Rh}_{0.5} / \mathrm{SBA}-15$ nevertheless demonstrate the positive effect of the presence of Co. From figure 7 , it also appears that $\mathrm{CO}_{2}$ conversions are always slightly higher than methane ones on both $\mathrm{Co}_{12} / \mathrm{SBA}-15$ and $\mathrm{Co}_{12} / \mathrm{SiO}_{2}$ catalysts. This indicates the occurrence of side reactions, probably reverse water gas shift at medium temperatures $\left(\mathrm{CO}_{2}+\mathrm{H}_{2} \rightarrow \mathrm{CO}+\mathrm{H}_{2} \mathrm{O}\right)[24,26]$. The conversions of both reactants are on the contrary very close on the Rh-containing samples. It was previously reported for $\mathrm{Ni}$ containing MCM-41 catalysts that $\mathrm{Rh}$ incorporation decreases the 
relative significance of the reverse water gas shift reaction with respect to dry reforming of methane [41]. Therefore, not only the activity of the Co/SBA-15 catalysts but also the side reactions occurrence decreased by the addition of rhodium, in line with a previous paper on $\mathrm{Rh}$ doped $\mathrm{Co} / \mathrm{Al}_{2} \mathrm{O}_{3}$ catalysts tested in DRM [12]. This result can also be seen on figure 8 that reports the $\mathrm{H}_{2}$ :CO ratios measured during stability tests. Thus, the ratio is near one in presence of rhodium, as expected from the DRM reaction alone, but it is significantly lower, below 0.6 , for both cobalt monometallic catalysts, confirming strong occurrence of side reactions.

\section{Figure 7 and Figure 8}

\subsection{Physicochemical properties of the spent catalysts}

In order to check eventual sintering and coke deposition effects on the catalysts throughout time-on-stream (after stability tests), the spent $\mathrm{Co}_{12} / \mathrm{SBA}-15, \quad \mathrm{Rh}_{0.2} \mathrm{Co}_{12} / \mathrm{SBA}-15$ and $\mathrm{Rh}_{0.5} \mathrm{Co}_{12} / \mathrm{SBA}-15$ samples were characterized by HRTEM and TPH/MS.

In the case of the spent $\mathrm{Co}_{12} / \mathrm{SBA}-15$ catalyst, the HRTEM images reveal significant cobalt migration outside the pores associated with a consequent sintering of the nanoparticles, both leading to the formation of external particles with diameters as big as 10-30 nm (Fig. 9a-c). For the reduced $\mathrm{Co}^{0}$ nanoparticles still present inside the pores, their average size is also increased since it reaches $11.6 \mathrm{~nm}$ whereas it was $8.6 \mathrm{~nm}$ for the cobalt oxide species present before reduction and catalytic run. It is worth recalling here that, in absence of sintering, the average size should be lower in the reduced catalyst due to the replacement of bulkier $\mathrm{Co}_{3} \mathrm{O}_{4}$ by reduced $\mathrm{Co}^{0}$. This further demonstrates the high sensitivity of the $\mathrm{Rh}-$ free $\mathrm{Co}_{12} / \mathrm{SBA}-15$ sample to sintering. Contrarily, the shape and location of the metal nanoparticles were found much more stable in $\mathrm{Rh}_{0.2} \mathrm{Co}_{12} / \mathrm{SBA}-15$ in which the active metal phase was predominantly maintained 
inside the pores after the catalytic run (Fig. 9 a'-c'). Furthermore, the average size of the reduced cobalt particles in spent $\mathrm{Rh}_{0.2} \mathrm{Co}_{12} / \mathrm{SBA}-15(8.3 \mathrm{~nm})$ was only slightly higher than on the fresh sample (around $6.6 \mathrm{~nm}$ ), thus further demonstrating that sintering is more limited in presence of rhodium, similarly to the case of $\mathrm{Ni} / \mathrm{Al}_{2} \mathrm{O}_{3}$ DRM catalysts doped with noble metals [54].

\section{Figure 9}

In addition to metal sintering effects, coke formed during reaction may also participate in deactivation. Due to the medium temperature $\left(550^{\circ} \mathrm{C}\right)$ applied during stability tests, the coke content was very low (hardly identified by HRTEM) but high enough (1-2 wt $\%$ ) to be detected on the spent catalysts by TPH/MS, a technique that can provide useful information about carbon nature $[55,56]$. In this technique, the coke reacts with hydrogen to form methane that is analyzed by following its mass (16). One advantage compared to other techniques currently used for coke identification (e.g. temperature programmed oxidation or thermal gravimetric analysis) is that it is carried out in the absence of oxygen, which ensures the absence of interferences with other possible phenomena such as metal active phase reoxidation. Moreover, it permits to discriminate the three different types of coke $(\mathrm{C} \alpha, \mathrm{C} \beta$ and $\mathrm{C} \gamma)$ commonly identified depending on the temperature at which they react with hydrogen (see details in section 2.2). We can recall that $\mathrm{C} \alpha$ is known as a reaction intermediate that does not affect the stability, whereas $\mathrm{C} \beta$ (evolved at medium temperature) corresponds to nanotubes precursor species and graphitic $\mathrm{C} \gamma$ (evolved at high temperatures) is known for its strong deactivation effect $[31,56,57,58]$. The origins of these different carbons are threefold: (i) active $\mathrm{C}^{*}(\mathrm{C}$ adsorbed on an active metal site) reacting with adsorbed oxygen species to give $\mathrm{CO}$, (ii) $\mathrm{C}^{*}$ leading to inactive $\mathrm{C}$ deposit on $\operatorname{metal}^{\circ}$ due to the lack of adjacent oxygen species or (iii) $\mathrm{C}$ deposit after carbon migration from metal sites to the 
support. It is worth noting that the first type of carbon is an intermediate in the reaction, which does not lead to deactivation of the catalyst $[59,60]$.

\section{Figure 10}

The percentages of different types of coke $\mathrm{C} \alpha, \mathrm{C} \beta$ and $\mathrm{C} \gamma$ were deduced from the TPH-MS profiles, following the same methodology as described in our recent paper [56], for the spent $\mathrm{Co}_{12} / \mathrm{SBA}-15, \quad \mathrm{Rh}_{0.2} \mathrm{Co}_{12} / \mathrm{SBA}-15, \quad \mathrm{Rh}_{0.5} \mathrm{Co}_{12} / \mathrm{SBA}-15$ and $\mathrm{Rh}_{0.5} / \mathrm{SBA}-15$ catalysts and are presented in Figure 10. All the catalysts contain the three types of coke but in different percentages. In the $\mathrm{Co}_{12} / \mathrm{SBA}-15$ catalyst, 7,54 and $39 \%$ of the deposited carbon are in the forms of $\mathrm{C} \alpha, \mathrm{C} \beta$ and $\mathrm{C} \gamma$, respectively. The $\mathrm{Rh}_{0.2} \mathrm{Co}_{12} / \mathrm{SBA}-15$ catalyst presents a similar proportion of $\mathrm{C} \alpha$, but it contains less $\mathrm{C} \gamma(10 \%$ instead of $39 \%)$ that is known as the heaviest and most detrimental type of coke for catalysts stability [56]. Finally, it is clear that $\mathrm{Rh}_{0.5} \mathrm{Co}_{12} / \mathrm{SBA}-15$ contains the lowest $\mathrm{C} \gamma$ amount and the highest amount of $\mathrm{C} \alpha$ that is known to be an intermediate in the DRM reaction, with no deleterious impact on the reaction [56]. In light of these results, we can say that the DRM mechanism is not similar on cobalt and rhodium active sites. For the highest rhodium content, an equivalent percentage of carbon reaction intermediate was obtained which means that adsorbed oxygen species are present in higher percentage in presence of rhodium. This indicates that oxygen activated species are more easily adsorbed on rhodium than on cobalt sites and this is the main reason behind the higher conversion of reactants on the rhodium containing catalysts. Finally, it is worth mentioning that the presence of the two metals, rhodium and cobalt, leads to a minimization of the most deactivating carbon type $(\mathrm{C} \gamma)$ that originates from the deposition of carbon on metal rather than onto the support. This latter 
observation shows the importance of using catalysts loaded with the two metals and their advantages compared to monometallic ones.

\section{Conclusion}

SBA-15 improves the textural and morphological properties of the catalysts by preserving the high active phase dispersion inside the mesoporosity of the support when used instead of nonporous silica. The use of mesoporous silica SBA-15 as support of cobalt active nanoparticles (12 wt $\%$ ) together with doping by small amounts of rhodium (up to $0.5 \mathrm{wt} \%$ ) leads to highly active and stable catalysts in DRM as good as those Ni/SBA-15 catalysts described in the literature. The occlusion of the cobalt nanospecies inside the mesopores of the silica grains strongly enhances their stability against sintering. Rhodium promotes their reducibility under hydrogen and it enhances the catalytic performances by participating to the reaction. Furthermore when present with cobalt, rhodium affects the nature of the coke formed on the spent catalysts by minimizing the formation of the most destructive type of coke $(\mathrm{C} \gamma)$.

\section{Acknowledgments}

Authors would like to thank the UOB research council for financial support through the BIRG 14/2012 and the CEDRE France-Lebanon Hubert-Curien (PHC) program for project $\mathrm{N}^{\circ}$ 30962ZH (2014-2015). Thanks also to Miss Hala Fallah for the help in the experimental part $\left(\mathrm{N}_{2}\right.$ sorption, X-Ray diffraction and particles counting) and Miss Ranim Hajal for particles counting. 


\section{List of References:}

[1] V. Havran, M.P. Dudukovic, C.S. Lo, Ind. Eng. Chem. Res. 50 (2011) 7089-7100.

[2] R. Horn, R. Schloegl, Cat. Lett. 145 (2015) 23-39.

[3] Y. Shah, T. Gardner, Catal. Rev. 56 (2014) 476-536.

[4] D. Pakhare, J. Spivey, Chem. Soc. Rev. 43 (2014) 7813-7837.

[5] Z. Hou, P. Chen, H. Fang, X. Zheng, T.Yashima, Int. J. Hydrogen Energ. 31 (2006) 555561.

[6] S. Li, J. Gong, Chem. Soc. Rev. 43 (2014) 7245-7256.

[7] A.W. Budiman, S. H.Song, T.S. Chang, C.H. Shin, M.J. Choi, Catal. Surv. Asia 16 (2012) 183-197.

[8] J.L. Ewbank, L. Kovarik, C.C. Kenvin, C. Sievers, Green Chem. 16 (2014) 885-896.

[9] D. Liu, W.N.E. Cheo, Y.W.Y. Lim, A. Borgna, R. Lau, Y. Yang, Catal. Today 154 (2010) 229-236.

[10] A.E. Abasaeed, A.S. Al-Fatesh, M.A. Naeem, A.A. Ibrahim, A.H. Fakeeha, Int. J. Hydrogen Energ. 40 (2015) 6818-6826.

[11] G. Zhang, A. Su, Y. Du, J. Qu, Y. Xu, J. Colloid Interf. Sci. 433 (2014) 149-155.

[12] Z. Ferencz, K. Baan, A. Oszko, Z. Konya, T. Kecskes, A. Erdohelyi, Catal. Today 228 (2014) 123-130. 
[13] P. Ferreira-Aparicio, A. Guerrero-Ruiz, I. Rodriguez-Ramos, Appl. Catal. A-Gen. 170 (1998) 177-187.

[14] R. Bouarab, O. Akdim, A. Auroux, O. Cherifi, C. Mirodatos, Appl. Catal. A-Gen. 264 (2004) 161-168.

[15] K. Jabbour, N. El Hassan, S. Casale, J. Estephane, H. El Zakhem, Int. J. Hydrogen Energ. 39 (2014) 7780-7787.

[16] A.I. Paksoy, B.S. Caglayan, A.E. Aksoylu, Appl. Catal. B-Environ. 168 (2015) 164-174.

[17] M.S. Aw, M. Zorko, I.G. Osojnik Crnivec, A. Pintar, Ind. Eng. Chem. Res. 54 (2015) 3775-3787.

[18] M.S. Aw, M. Zorko, P. Djinovic, A. Pintar, Appl. Catal. B-Environ. 164 (2015) 100-112.

[19] L. Li, D.H. Anjum, H. Zhu, Y. Saih, P.V. Laveille, L. D'Souza, J.M. Basset, ChemCatChem 7 (2015) 427-433.

[20] M.S. Aw, I.G.O. Crnivec, P. Djinovic, A. Pintar, Int. J. Hydrogen Energ. 39 (2014) 1263612647.

[21] M.S. Aw, I.G.O. Crnivec, A. Pintar, Catal. Commun. 52 (2014) 10-15.

[22] I. Lopes, N. El Hassan, H. Guerba, G. Wallez, A. Davidson, Chem. Mater. 18 (2006) 58265828.

[23] N. El Hassan, A. Davidson, P. Da Costa, G. Djega-Mariadassou, Catal. Today 137 (2008) 191-196. 
[24] N. El Hassan, S. Aouad, S. Casale, H. El Zakhem, H. El Nakat, C.R. Chim. 17 (2014) 913919.

[25] M.N. Kaydouh, N. El Hassan, A. Davidson, S. Casale, H. El Zakhem, P. Massiani, C.R. Chim. 18 (2015) 293-301.

[26] E. Baktash, P. Littlewood, J. Pfrommer, R. Schomacker, M. Driess, A. Thomas, ChemCatChem 7 (2015) 1280-1284.

[27] A. Albarazi, M. E. Galvez, P. Da Costa, Catal. Commun. 59 (2015) 108-112.

[28] M.N. Kaydouh, N. El Hassan, A. Davidson, S. Casale, H. El Zakhem, P. Massiani, Microp. Mesop. Mater., 220 (2016) 99-109.

[29] L. Qian, Z. Ma, Y. Ren, H. Shi, B. Yue, S. Feng, J. Shen, S. Xie, Fuel 122 (2014) 47-53.

[30] N. Wang, W. Chu, T. Zhang, X. S. Zhao, Int. J. Hydrogen Energ. 37 (2012) 19-30.

[31] S. Zhang, S. Muratsugu, N. Ishiguro, M. Tada, ACS Catal. 3 (2013) 1855-1864.

[32] C. Crisafulli, S. Scire, R. Maggiore, S. Minico, S. Galvagno, Catal. Lett. 59 (1999) 21-26.

[33] C. Crisafulli, S. Scire, S. Minico, L. Solarino, Appl. Catal. A-Gen. 225 (2002) 1-9.

[34] K. Tomishige, S. Kanazawa, M. Sato, K. Ikushima, K. Kunimori, Catal. Lett. 84 (2002) 69-74.

[35] Z. Hou, T. Yashima, Catal. Lett. 89 (2003) 193-197.

[36] C.J. Liu, J. Ye, J. Jiang, Y. Pan, ChemCatChem 3 (2011) 529-541.

[37] J.C.S. Wu, H.C. Chou, Chem. Eng. J. 148 (2009) 539-545. 
[38] M. Nowosielska, W.K. Jozwiak, J. Rynkowski, Catal. Lett. 128 (2009) 83-93.

[39] W.K. Jozwiak, M. Nowosielska, J. Rynkowski, Appl. Catal. A-Gen. 280 (2005) 233-244.

[40] H. Arbag, S. Yasyerli, N. Yasyerli, G. Dogu, Int. J. Hydrogen Energ. 35 (2010) 2296-2304.

[41] S. Irusta , L.M. Cornaglia, E.A. Lombardo, J. Catal. 210 (2002) 263-272.

[42] P. Ferreira-Aparicio, M.J. Benito, Ind. Eng. Chem. Res. 44 (2005) 742-748.

[43] S. Sokolov, E.V. Kondratenko, M.M. Pohl, A. Barkschat, U. Rodemerck, Appl. Catal. BEnviron. 113 (2012) 19-30.

[44] D. Baudouin, U. Rodemerck, F. Krumeich, A.D. Mallmann, K.C. Szeto, H. Ménard, L. Veyre, J. Candy, P.B. Webb, C. Thieuleux, C. Copéret, J. Catal. 297 (2013) 27-34.

[45] X. Xie, T. Otremba, P. Littlewood, R. Schomaacker, A. Thomas, ACS Catal. 3 (2013) 224229.

[46] S. Sokolov, E.V. Kondratenko, M.M. Pohl, U. Rodemerck, Int. J. Hydrogen Energ. 38 (2013) 16121-16132.

[47] D.Y. Zhao, J.L. Feng, Q.S. Huo, N. Melosh, G.H. Fredrickson, B.F. Chmelka, G.D. Stucky, Science 279 (1998) 548-552.

[48] M. Imperor-Clerc, D. Bazin, M.D. Appay, P. Beaunier, A. Davidson, Chem. Mater. 16 (2004) 1813-1821.

[49] F. Boubekr, A. Davidson, S. Casale, P. Massiani, Microp. Mesop. Mater. 141 (2011) 157166. 
[50] A. Martinez, C. Lopez, F. Marquez, I. Diaz, J. Catal. 220 (2003) 486-499.

[51] A.Y. Khodakov, R. Bechara, A. Griboval-Constant, Appl. Catal. A-Gen. 254 (2003) 273288.

[52] W. Cai, F. Wang, A.C. Van Veen, H. Provendier, C. Mirodatos, W. Shen, Catal. Today 138 (2008) 152-156.

[53] M. Ocsachoque, F. Pompeo, G. Gonzalez, Catal. Today 172 (2011) 226- 231

[54] F. Morales-Cano, L.F. Lundegaard, R.R. Tiruvalam, H. Falsig, M. S. Skjøth-Rasmussen, Appl. Catal. A-Gen. 498 (2005) 117-125.

[55] M. Rezaei, S.M. Alavi, S. Sahebdelfar, Z.F. Yan, J. Nat. Gas Chem. 15 (2006) 327-334.

[56] K. Jabbour, N. El Hassan, A. Davidson, P. Massiani, S. Casale, Chem. Eng. J. 264 (2015) $351-358$.

[57] J. Xu, W. Zhou, J. Wang, Z. Li, J. Ma, Chin. J. Catal. 30 (2009) 1076-1084.

[58] Z.L. Zhang, X.E. Verykios, Catal. Today 21 (1994), 589-96.

[59] M. Maestri, D. G. Vlachos, A. Beretta , G. Groppi , E. Tronconi J. Catal. 259 (2008) 211222.

[60] A. Donazzi, A. Beretta, G. Groppi, P. Forzatti, J. Catal. 255 (2008) 259-268. 


\section{Figures Captions}

Figure 1: $\mathrm{N}_{2}$ sorption isotherms on the SBA-15 support and on calcined impregnated samples.

Figure 2: XRD patterns of calcined materials (* and o show the expected peak positions for crystalline $\mathrm{CO}_{3} \mathrm{O}_{4}$ and for $\mathrm{Rh}$ oxide, respectively).

Figure 3: Typical TEM images of grains of (a-c) $\mathrm{Co}_{12} / \mathrm{SBA}-15$ and $\left(\mathrm{a}^{\prime}-\mathrm{c}^{\prime}\right) \mathrm{Rh}_{0.5} \mathrm{Co}_{12} / \mathrm{SBA}-15$ calcined materials with porous network oriented $\left(a, a^{\prime}\right)$ along or $\left(b, b^{\prime}\right.$ and $\left.c, c^{\prime}\right)$ perpendicular to the electron beam.

Figure 4: Typical HRTEM images showing (a) $\mathrm{CO}_{3} \mathrm{O}_{4}$ nanoparticles occluded in the pores of $\mathrm{Co}_{12} / \mathrm{SBA}-15$, (b) their aggregation along the channels in $\mathrm{Rh}_{0.2} \mathrm{CO}_{12} / \mathrm{SBA}-15$ and (c) the presence of very small isolated $\mathrm{Rh}$ oxide nanoparticles (indicated by the arrows) in $\mathrm{Rh}_{0.5} \mathrm{Co}_{12} / \mathrm{SBA}-15$.

Figure 5: TPR profiles of calcined samples.

Figure 6: Evolution of $(A) \mathrm{CH}_{4}$ and $(B) \mathrm{CO}_{2}$ conversions with temperature on the reduced catalysts $(\mathrm{P}=1$ bar, $\mathrm{CH}_{4}: \mathrm{CO}_{2}=1$ and GHSV of $\left.67 \mathrm{~L} \cdot \mathrm{g}^{-1} \cdot \mathrm{h}^{-1}\right)$.

Figure 7: Evolution of (A) $\mathrm{CH}_{4}$ and (B) $\mathrm{CO}_{2}$ conversions as a function of time-on-stream during stability tests at $550^{\circ} \mathrm{C}\left(\mathrm{P}=1 \mathrm{bar}, \mathrm{CH}_{4}: \mathrm{CO}_{2}=1\right.$ and GHSV of $\left.67 \mathrm{~L} \cdot \mathrm{g}^{-1} \cdot \mathrm{h}^{-1}\right)$.

Figure 8: Evolution of $\mathrm{H}_{2}$ : $\mathrm{CO}$ ratio products ratio as a function of time-on-stream during stability tests at $550^{\circ} \mathrm{C}\left(\mathrm{P}=1\right.$ bar, $\mathrm{CH}_{4}: \mathrm{CO}_{2}=1$ and GHSV of $\left.67 \mathrm{~L} \cdot \mathrm{g}^{-1} \cdot \mathrm{h}^{-1}\right)$.

Figure 9: Typical TEM images of the spent (a-c) $\mathrm{Co}_{12} / \mathrm{SBA}-15$ and $\left(\mathrm{a}^{\prime}-\mathrm{c}^{\prime}\right) \mathrm{Rh}_{0.5} \mathrm{Co}_{12} / \mathrm{SBA}-15$ catalysts.

Figure 10: Distribution of the different types of coke $C_{\alpha}, C_{\beta}$ and $C_{\gamma}$ on the spent catalysts. 
Figure 1

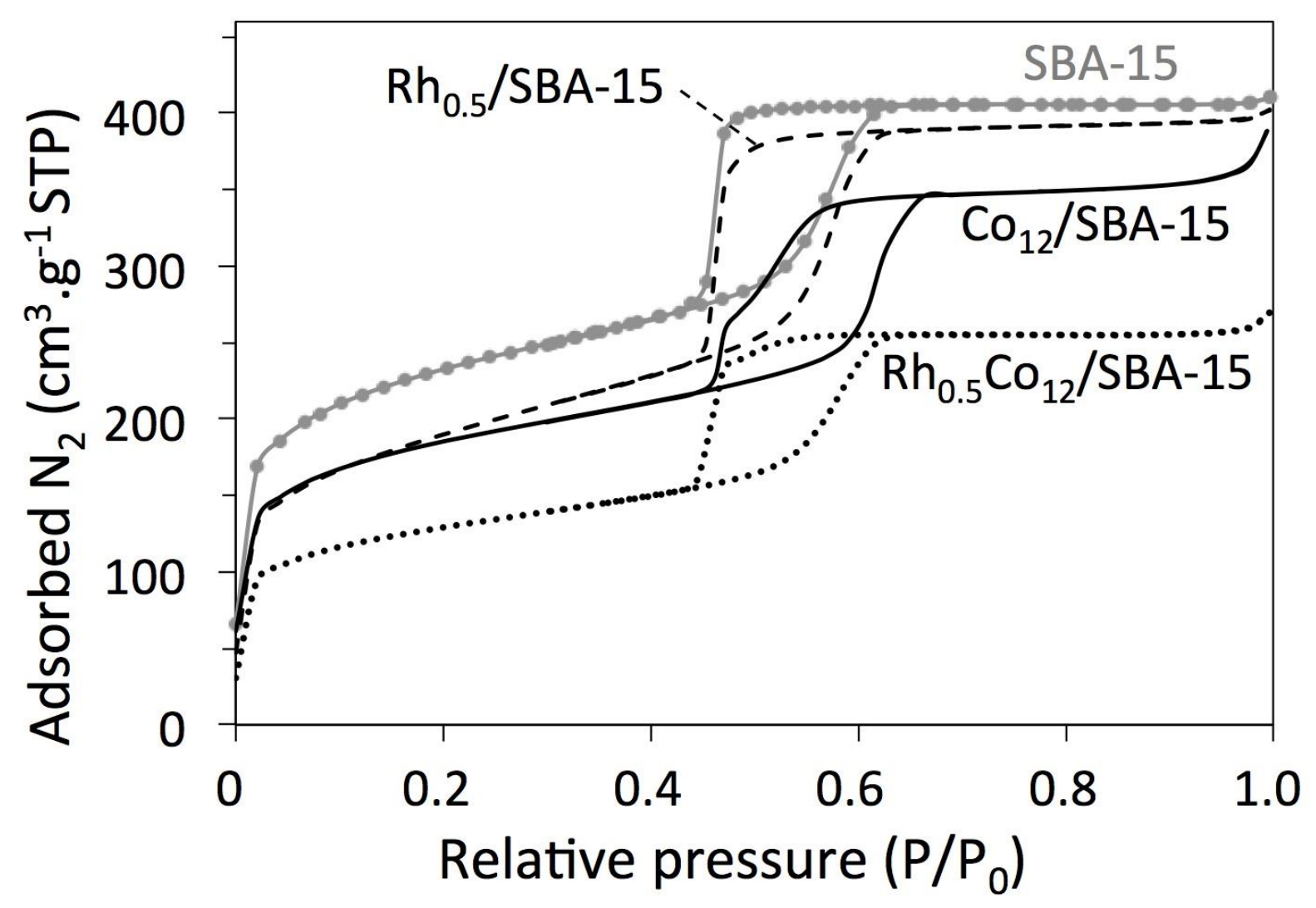


Figure 2

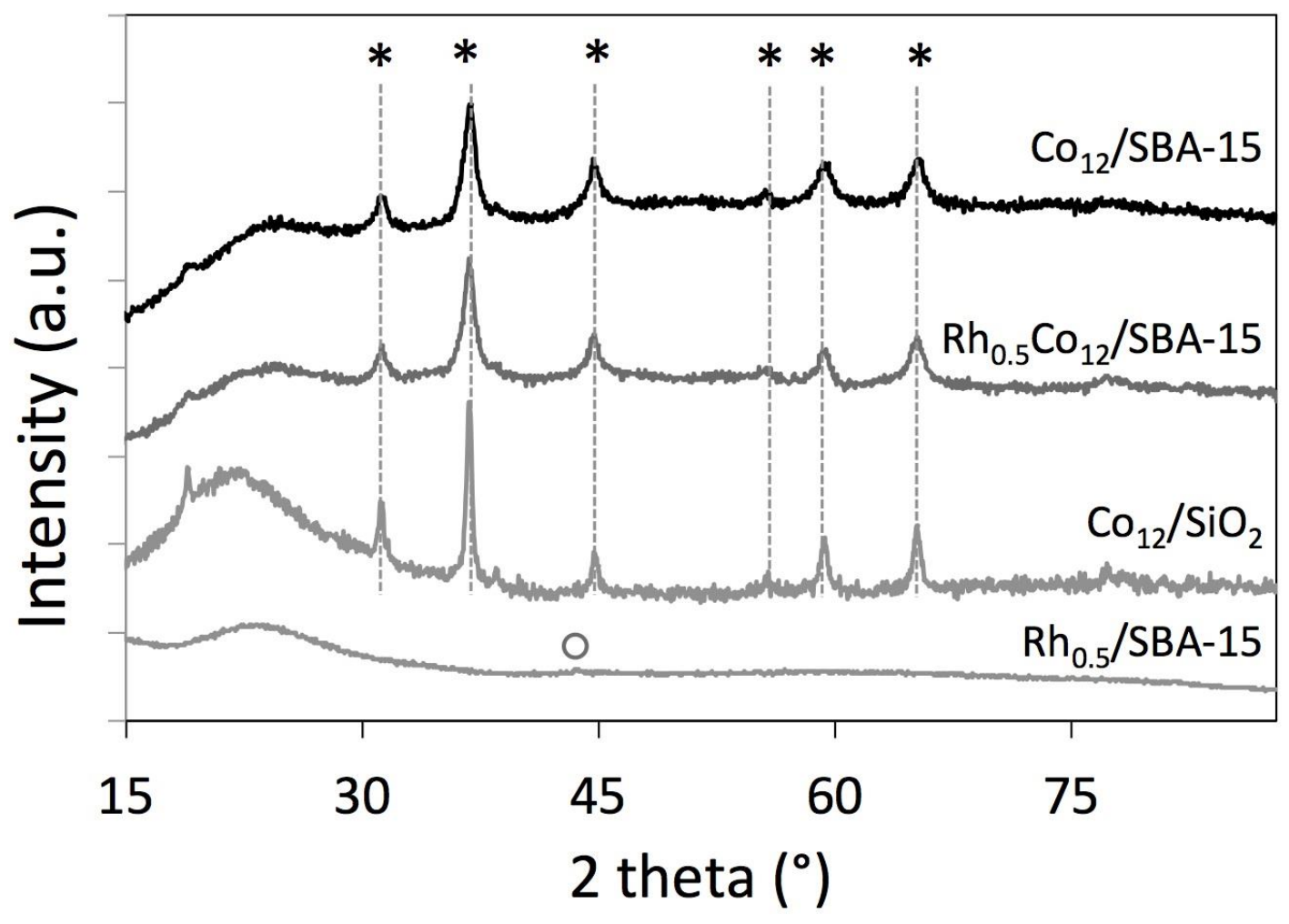


Figure 3
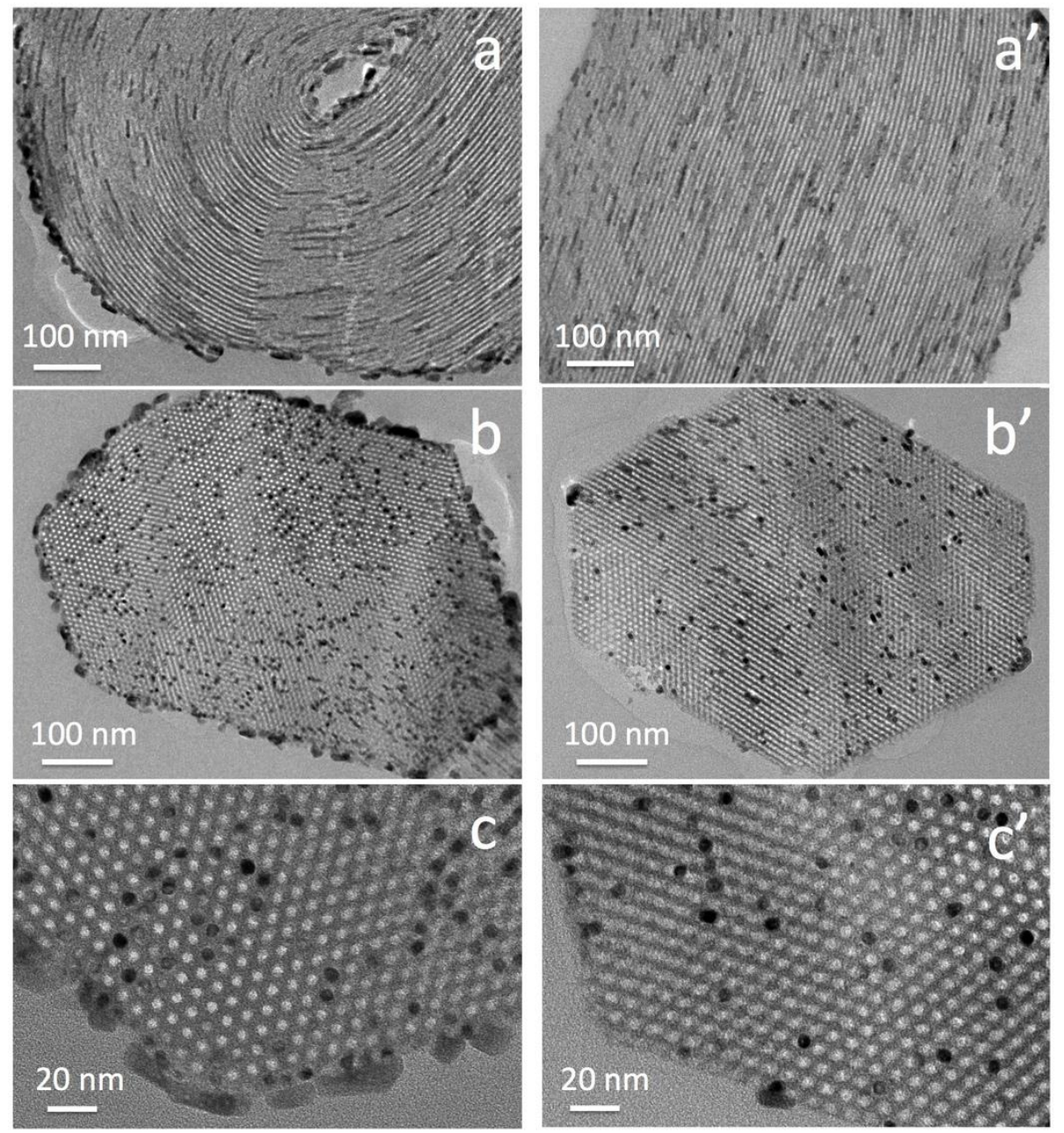
Figure 4
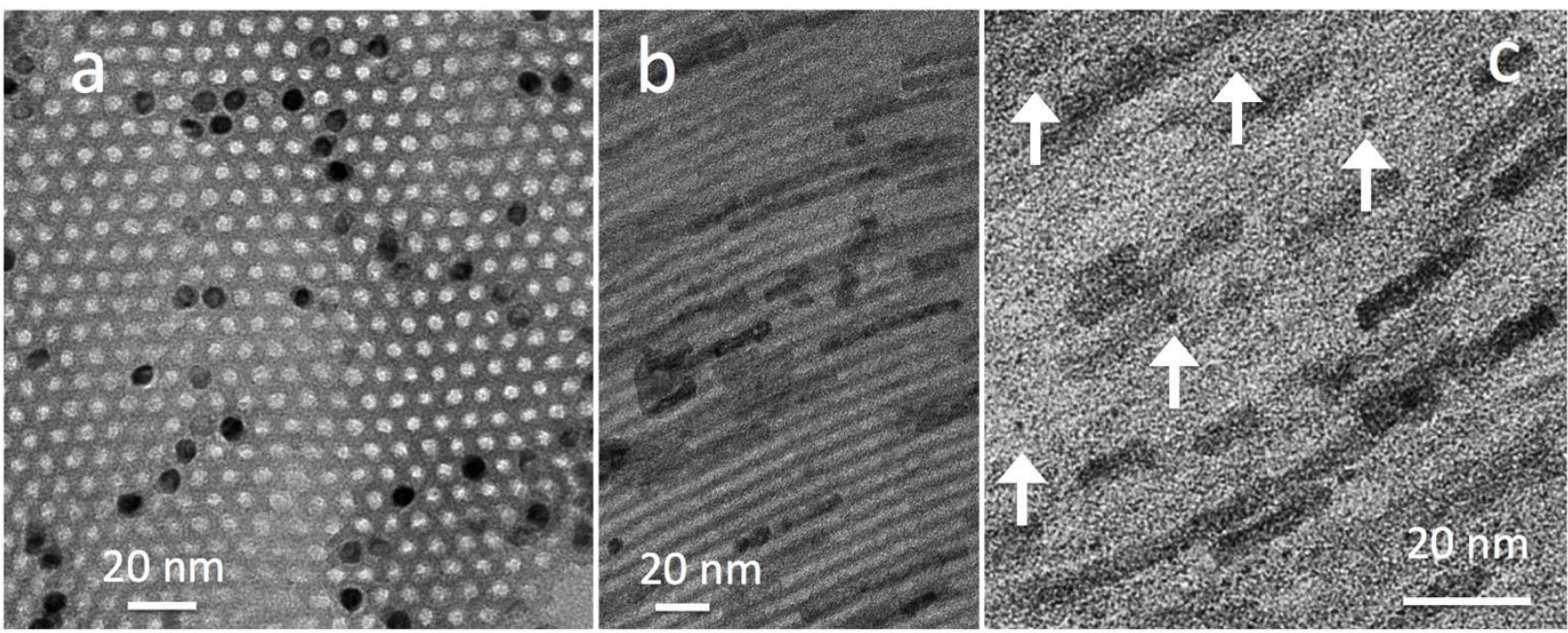
Figure 5

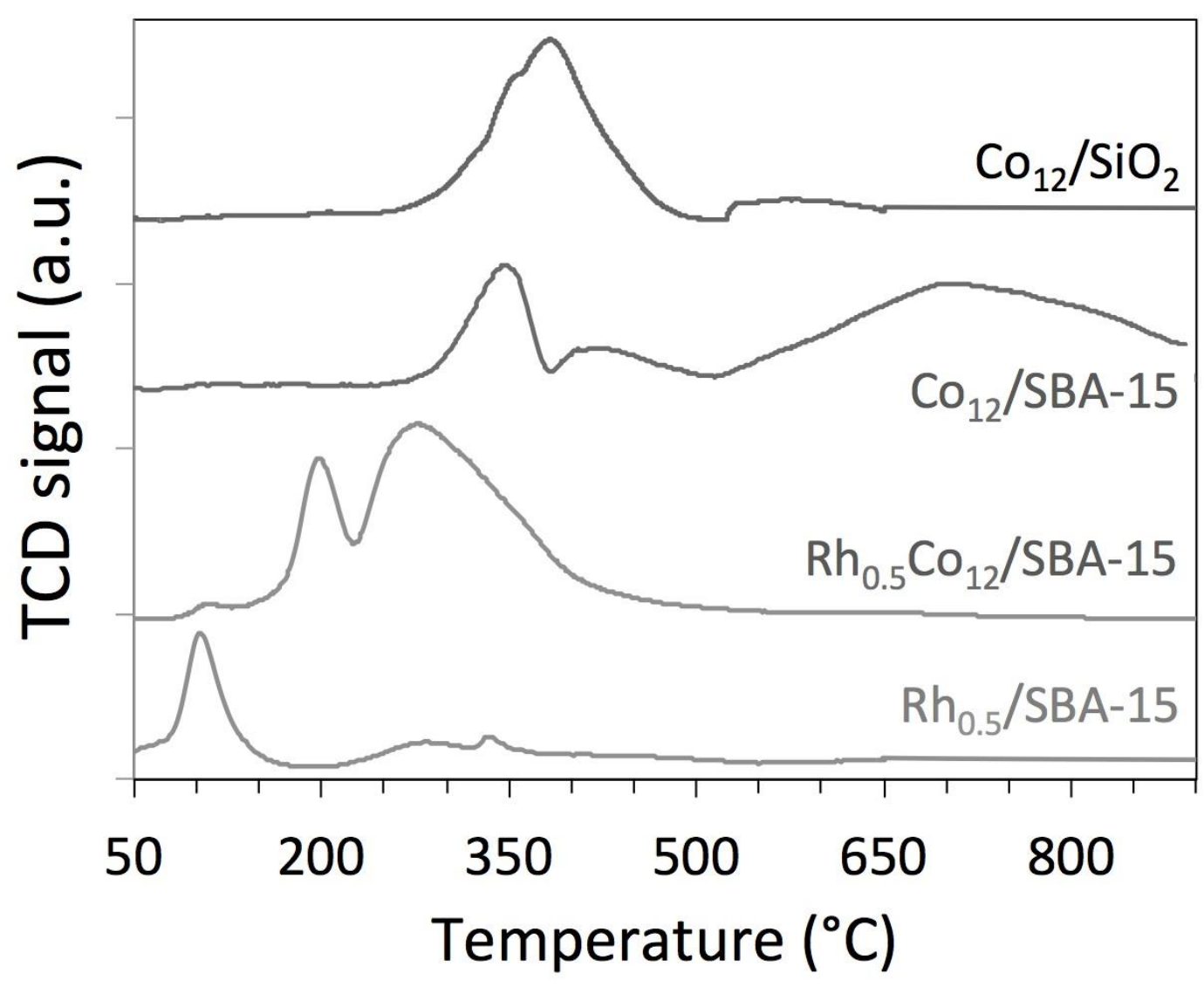


Figure 6




Figure 7

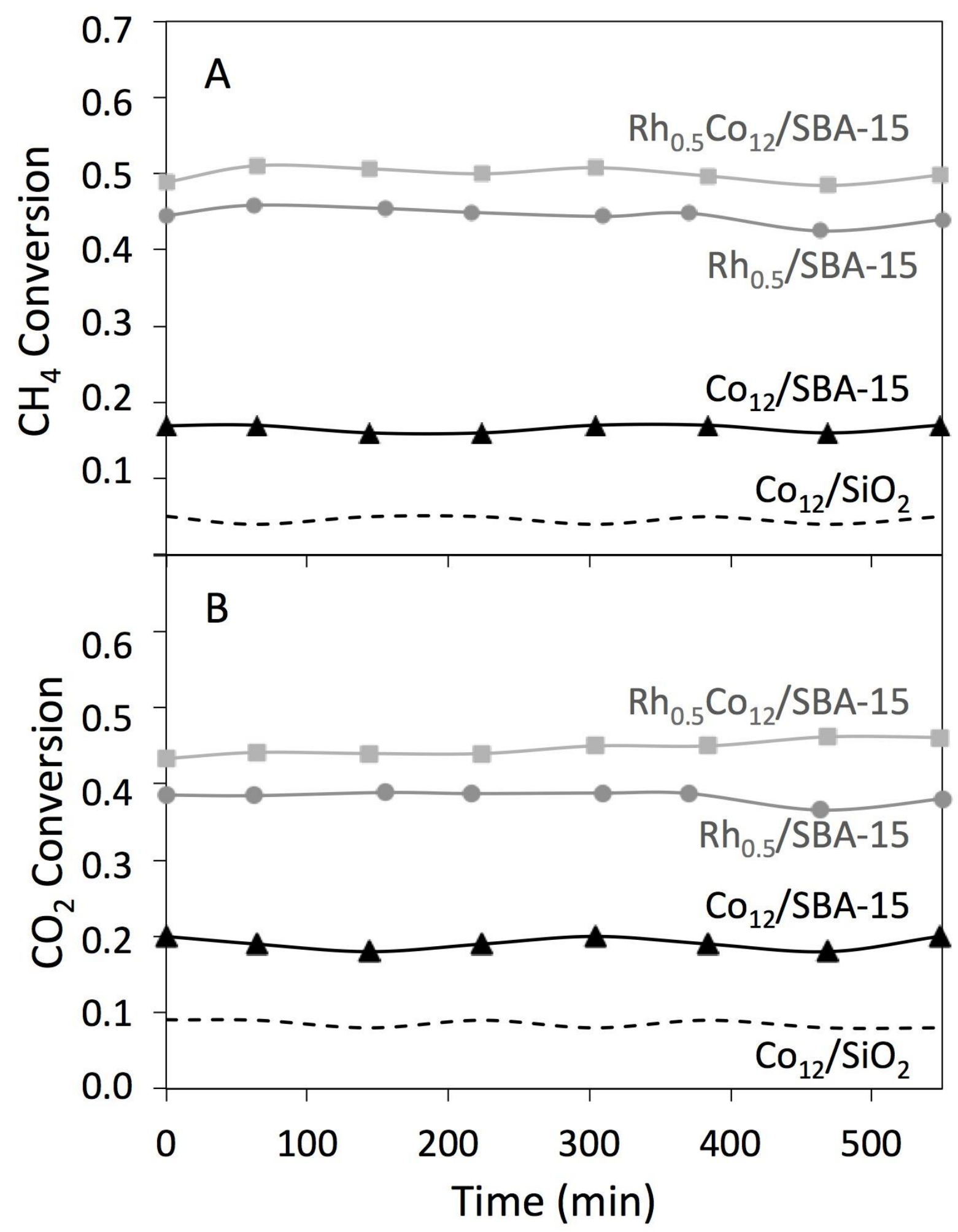


Figure 8

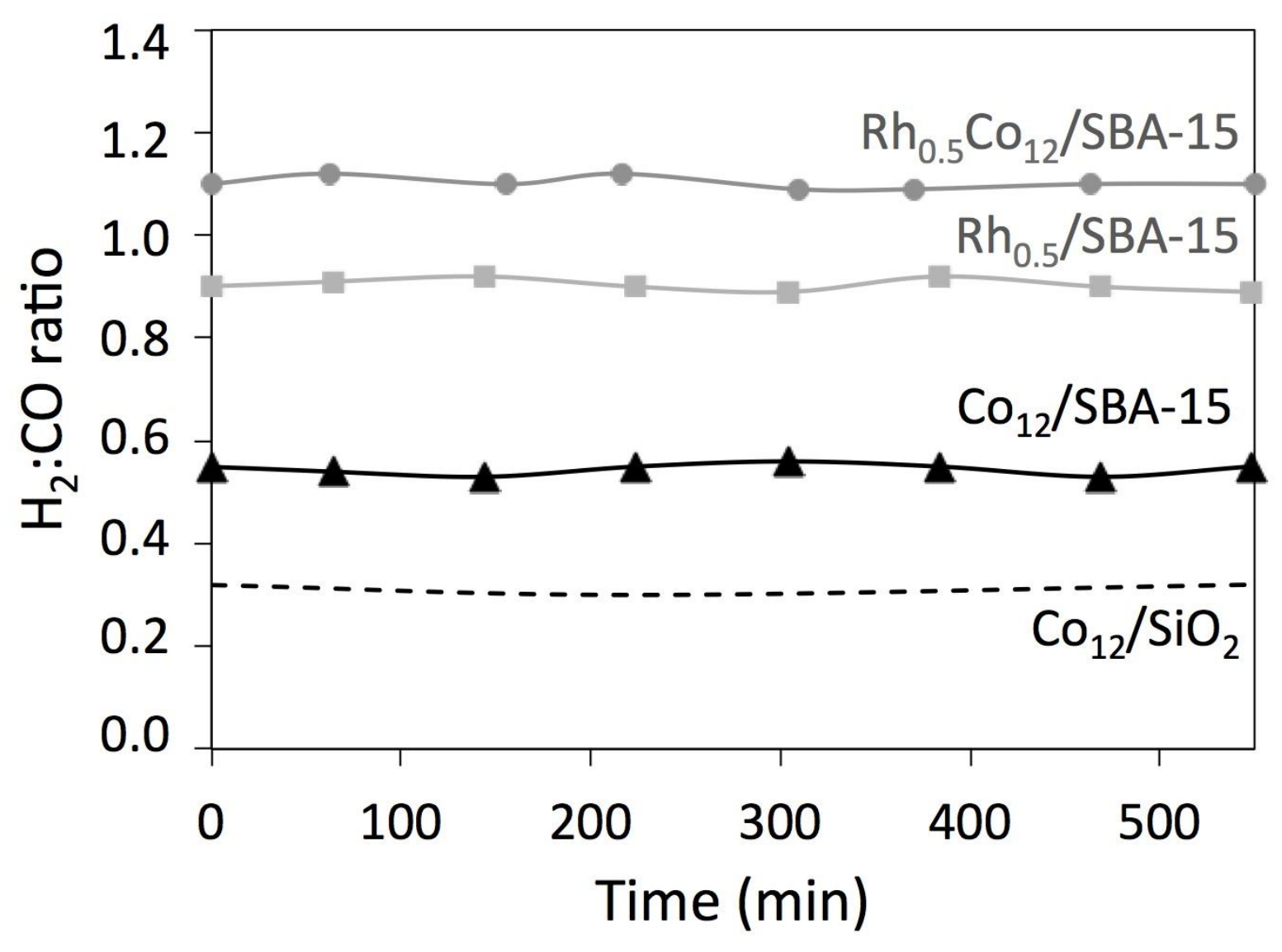


Figure 9
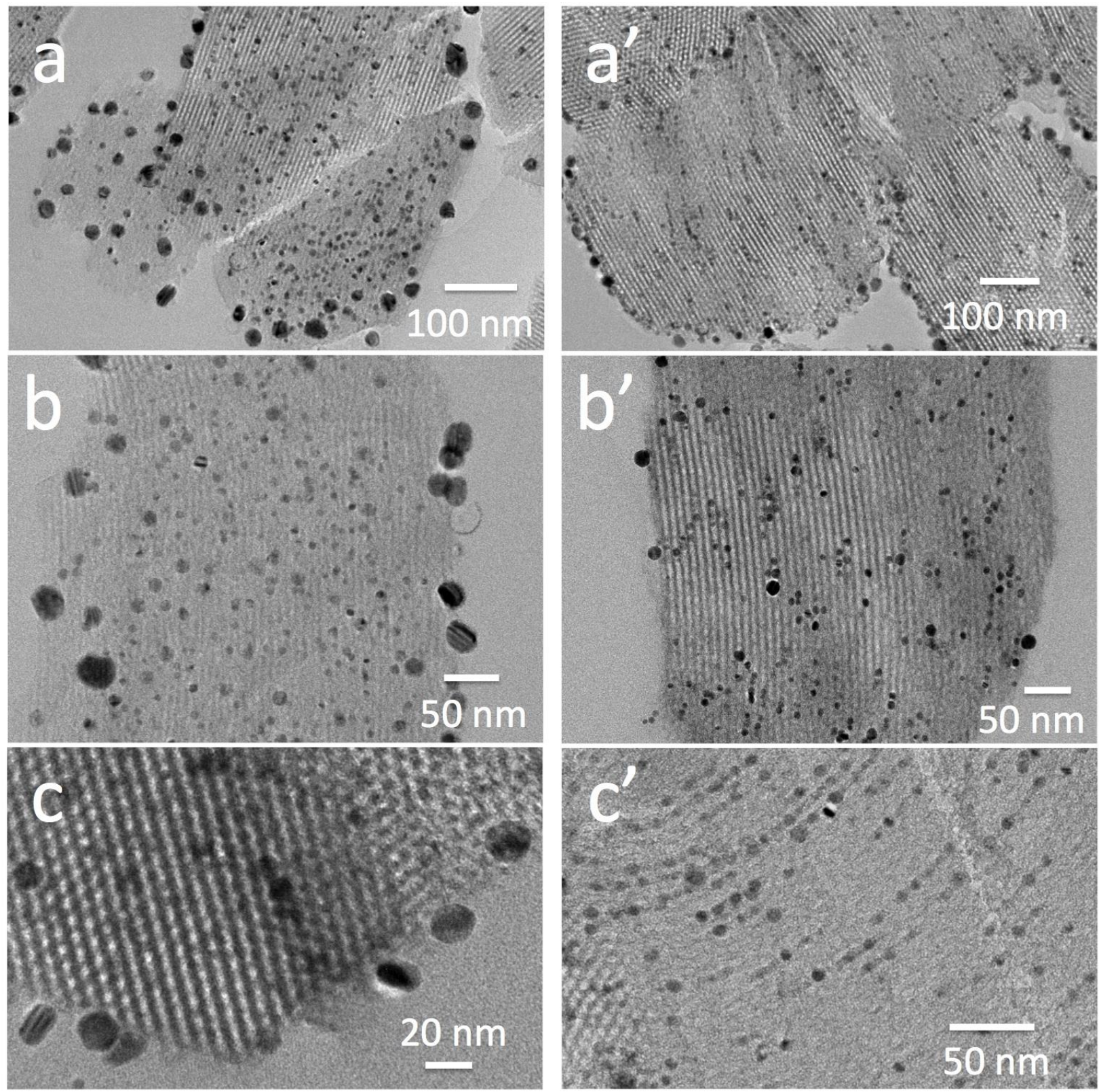
Figure 10

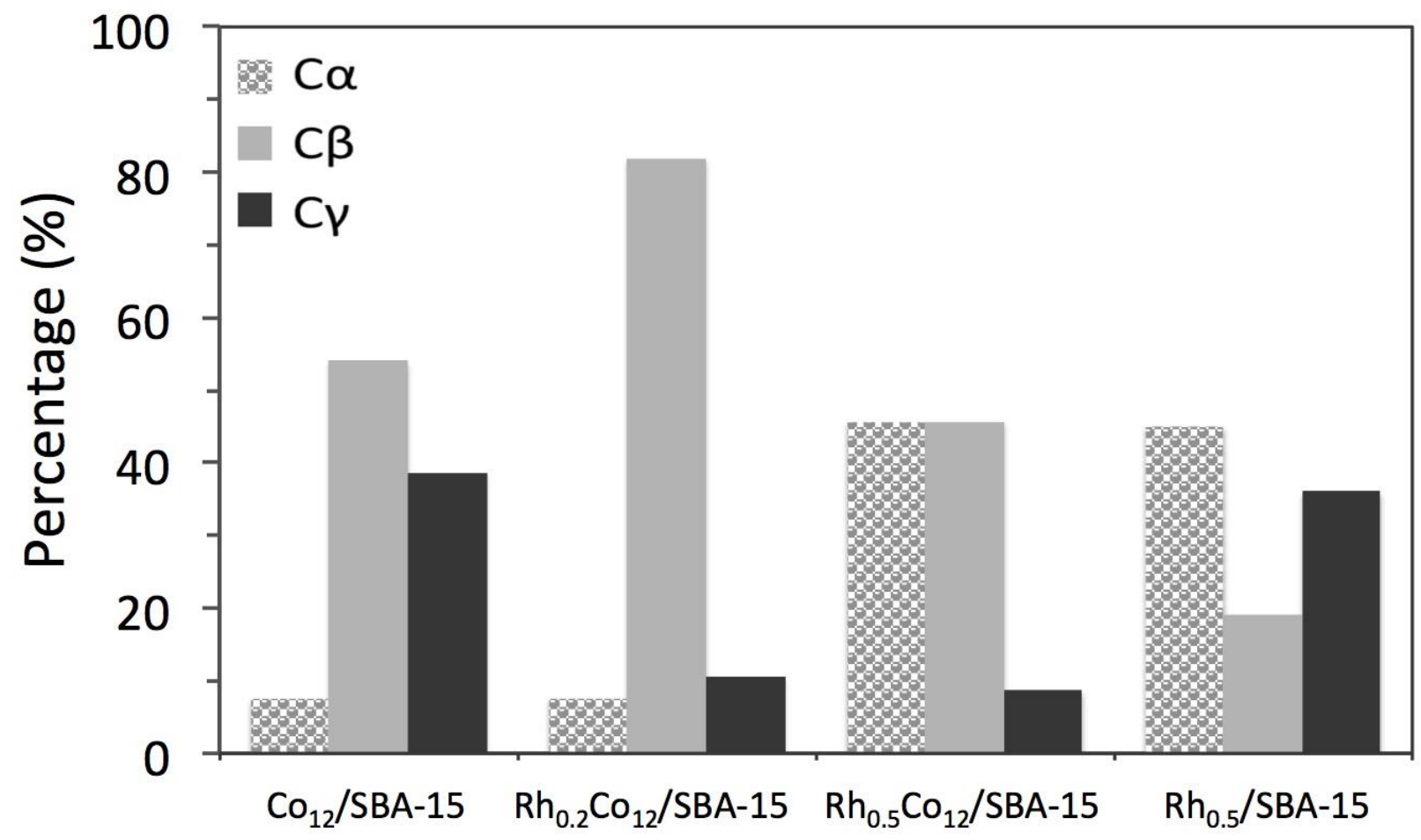


Table 1: Textural properties and mean diameter of the Co-based nanoparticles in the calcined and spent samples

\begin{tabular}{|c|c|c|c|c|c|c|}
\hline & SBA-15 & $\mathrm{Co}_{12} / \mathrm{SBA}-15$ & $\mathbf{R h}_{0.5} / \mathrm{SBA}-15$ & $\begin{array}{c}\mathrm{Rh}_{0.2} \mathrm{Co}_{12} / \mathrm{SBA}- \\
15\end{array}$ & $\begin{array}{c}\mathrm{Rh}_{0.5} \mathrm{Co}_{12} / \mathrm{SBA}- \\
15\end{array}$ & $\mathrm{Co}_{12} / \mathrm{SiO}_{2}$ \\
\hline $\begin{array}{l}\text { Total Surface } \\
\text { Area }\left(\mathrm{m}^{2} \cdot \mathrm{g}^{-1}\right)\end{array}$ & 803 & 639 & 668 & 448 & 446 & 171 \\
\hline $\begin{array}{c}\text { Microporous } \\
\text { volume }\left(\mathrm{cm}^{3} \cdot \mathrm{g}^{-1}\right)\end{array}$ & 0.32 & 0.20 & 0.19 & 0.13 & 0.13 & 0.01 \\
\hline $\begin{array}{c}\text { Mesoporous } \\
\text { volume }\left(\mathrm{cm}^{3} \cdot \mathrm{g}^{-1}\right)\end{array}$ & 0.48 & 0.43 & 0.53 & 0.33 & 0.32 & - \\
\hline $\begin{array}{l}\text { Average pore } \\
\text { diameter (nm) }\end{array}$ & 3.7 & 3.7 & 3.8 & 3.7 & 3.6 & - \\
\hline $\begin{array}{c}\text { Total } \mathrm{H}_{2} \\
\text { consumption } \\
\left(\mu \text { mol. } \mathrm{g}^{-1}\right)\end{array}$ & - & 2356 & 171 & 2807 & 2843 & 2324 \\
\hline $\mathrm{dCo}_{3} \mathrm{O}_{4}(\mathrm{a})$ & - & 8.6 & - & 7.1 & 7.1 & 16.4 \\
\hline $\mathrm{dCo}_{3} \mathrm{O}_{4}(\mathrm{~b})$ & - & 8.1 & - & 7 & 6.8 & - \\
\hline $\mathrm{dCo}^{0}(\mathrm{~b})$ & - & 11.6 & - & 8.3 & n.d. (c) & - \\
\hline
\end{tabular}
(a) Average particle diameter (nm) estimated from XRD (440 reticular plan)
(b) Average diameter $(\mathrm{nm})$ of spherical particles determined from TEM $( \pm 0.2 \mathrm{~nm})$
(c) Not determined 